\title{
Phenetic and Molecular Diversity of Nitrogen Fixating Plant Growth Promoting Azotobacter Isolated from Semiarid Regions of India
}

\author{
Devendra Jain $\left(\mathbb{D},{ }^{1}\right.$ Jyoti Sharma, ${ }^{1}$ Gunnjeet Kaur $\mathbb{D}^{1},{ }^{1,2}$ Ali Asger Bhojiya $\mathbb{D D}^{1,3}$ \\ Surya Chauhan, ${ }^{1}$ Vimal Sharma, ${ }^{1}$ Archna Suman $\mathbb{D}^{4},{ }^{4}$ Santosh Ranjan Mohanty $\mathbb{D}^{5}{ }^{5}$ \\ and Elina Maharjan ${ }^{6}{ }^{6}$ \\ ${ }^{1}$ Department of Molecular Biology and Biotechnology, Rajasthan College of Agriculture, Maharana Pratap University of Agriculture \\ and Technology, Udaipur, 313001 Rajasthan, India \\ ${ }^{2}$ School of Agricultural Sciences, Dr. K. N. Modi University, Newai, 304021, Tonk, India \\ ${ }^{3}$ Department of Agriculture and Veterinary Sciences, Mewar University, Gangrar, 312901, Chittorgarh, India \\ ${ }^{4}$ Division of Microbiology, ICAR-Indian Agricultural Research Institute, 11001, New Delhi, India \\ ${ }^{5}$ All India Network Project on Soil Biodiversity and Biofertilizers, Indian Institute of Soil Science, Indian Council of \\ Agricultural Research, 462038, Bhopal, M.P, India \\ ${ }^{6}$ Central Department of Microbiology, Tribhuvan University, Kirtipur, Kathmandu, Nepal
}

Correspondence should be addressed to Devendra Jain; devroshan@gmail.com and Elina Maharjan; mrjn.elina@gmail.com

Received 5 October 2020; Revised 20 December 2020; Accepted 29 December 2020; Published 11 January 2021

Academic Editor: Marta Laranjo

Copyright (C) 2021 Devendra Jain et al. This is an open access article distributed under the Creative Commons Attribution License, which permits unrestricted use, distribution, and reproduction in any medium, provided the original work is properly cited.

In the present study, 24 Azotobacter strains were isolated from soils of different areas of southern Rajasthan and characterized at biochemical, functional, and molecular levels. The isolated Azotobacter strains were gram negative and cyst forming when viewed under the microscope. These strains were also screened for their plant growth promoting activities and the ability of these isolates to survive under abiotic stress conditions viz. salt, $\mathrm{pH}$, temperature, and drought stress. All the isolates showed IAA, siderophore, HCN, and ammonia production, whereas seven Azotobacter strains showed phosphate solubilization. Amplified Ribosomal DNA Restriction Analysis (ARDRA) revealed significant diversity among Azotobacter strains and the dendrogram obtained differentiated twenty-four of the strains into two major clusters at a similarity coefficient of 0.64 . Qualitative and quantitative $\mathrm{N}_{2}$ fixation abilities of these strains were also detrained, and the amounts of acetylene reduced by Azotobacter strains were in the range of 1.31 to $846.56 \mathrm{nmol} \mathrm{C}_{2} \mathrm{H}_{4} \mathrm{mg}$ protein ${ }^{-1} \mathrm{~h}^{-1}$. The strains showing high nitrogen fixation ability with multiple PGP activities were selected for further pot studies, and these Azotobacter strains significantly increased the various plant growth parameters of maize plantlets. Furthermore, the best Azotobacter isolates were subjected to 16S rRNA sequencing and confirmed their identities as Azotobacter sp. The indigenous Azotobacter strains with multiple PGP activities could be further used for commercial production.

\section{Introduction}

In agriculture, nitrogen deficiency directly influences the yield and profitability of crop plants worldwide and can be overcome by the application of inorganic chemical fertilizers [1]. The increased use of nitrogen based inorganic chemical fertil- izers causes serious adverse effects on the physicochemical properties of soil, i.e., degradation of soil organic carbon (SOC) and soil acidification [2]. Plant growth promoting rhizobacteria (PGPR) provides a promising sustainable solution for increasing agricultural productivity by encouraging plant growth and using plenty of growth-promoting pathways, 
beneficial plant microbe interactions, etc. and thereby decreases the use of these inorganic chemical based fertilizers [3]. In agriculture, many plant growth promoting microorganisms such as Azotobacter, Rhizobium, and Pseudomonas are used as biofertilizers, which not only provide plant nutrition but also maintain the soil health.

Nitrogen fixing bacteria, especially from the genus Azotobacter, holds an important role in soil fertility [4], since it can provide fixed $\mathrm{N}_{2}$ to plants and promote plant growth by providing other necessary nutrients to plants. Azotobacter is gram-negative, nonsymbiotic diazotrophic bacteria that belongs to the Azotobacteriaceae family that can fix an average of $20 \mathrm{kgN} / \mathrm{ha} /$ per year which can be further increased through inoculation of potent strains [5].

The ecological distribution of Azotobacter spp. is a complicated subject that depends on soil characteristics and climate conditions [6]. There are around six species in the genus Azotobacter and among them Azotobacter chroococcum dominant in Indian soils [7]. Several researchers around the world have successfully used Azotobacter as PGPB in biological $\mathrm{N}_{2}$ fixation, increased nutrient availability in the rhizosphere, and induced root surface not only yielding attributes but also reduced production costs $[8,9]$.

Biotic and abiotic stress significantly affects crop production and can be overcome by the application of plant growth promoting rhizobacteria, which stimulates plant growth by employing a plethora of growth-promoting mechanisms [10]. Azotobacter not only has the capacity to fix atmospheric nitrogen but also has various PGP activities, which makes Azotobacter the most effective and widespread among the PGPR community [11].

Despite the availability of Azotobacter strains, there is still a need to isolate and characterize native potent indigenous strains adapted to the local environment, which can not only contribute to the formulation of effective bioinoculants but also have a more competitive ability to survive in field conditions [12]. Hence, the aim of this study was to isolate, screen, and characterize the local Azotobacter present in the rhizospheric soil of different districts of Rajasthan for various plant growth promoting attributes and to evaluate their nitrogen-fixing ability by the Acetylene Reduction Assay (ARA).

\section{Materials and Methods}

2.1. Isolation of Azotobacter. Isolation of Azotobacter sp. from rhizospheric soils was done by the procedure described by Upadhyay et al. [13]. The rhizospheric soil samples collected from the districts of Rajasthan viz. Udaipur, Banswara, Dungarpur, Rajsamand, and Chittorgarh and were stored at $4^{\circ} \mathrm{C}$ until processed (Supplementary data sheet Table: S1). Rhizosphere soil was diluted up to $10^{-7}$ dilutions under aseptic conditions, and Azotobacter strains were isolated on Nitrogen free Jensen's medium [14].

2.2. Morphological Characterization of Azotobacter Isolates. Morphological characterization based on colony characteristics viz. shape, size, appearance, color, gram staining, pig- ment production [15], and cyst formation [16] among isolated Azotobacter strains was observed.

2.3. Screening of Plant Growth Promoting (PGP) Attributes and Abiotic Stress Tolerance of Azotobacter. All Azotobacter strains were further screened for multiple plant growth promoting activities viz. IAA production, siderophore production, ammonia production, $\mathrm{HCN}$ production, phosphate solubilization, and different abiotic stress tolerance viz. $\mathrm{pH}$ tolerance, temperature tolerance, salinity tolerance, and drought tolerance according to the methodologies published in our previous research $[17,18]$.

2.4. Molecular Characterization Using ARDRA of the $16 \mathrm{~S}$ rDNA Region. The total genomic DNA of Azotobacter strains was carried out following the method outlined by Jain et al. [19]. The DNA patterns of the restriction digested 16S rDNA region were amplified and analyzed on agarose gel for all Azotobacter isolates as outlined by Jain et al. [19] and Kour et al. [17]. The 16S rDNA amplicons were digested with HinfI, AluI, and TaqI restriction endonucleases [20]. Data analysis was performed using the NTSYS-PC (Numerical Taxonomy and Multivariate Analysis System) software and SIMUQUAL Jaccards similarity coefficient [21].

2.5. Qualitative and Quantitative Estimation of Nitrogen Fixation. The qualitative nitrogen fixing ability of Azotobacter was detected in petri plates containing nitrogen-free malate media (NFM) with bromothymol blue (BTB) dye, and the positive strains produced a blue color zone around the inoculated strains. The amount of total nitrogen produced by Azotobacter in Jensen's broth was evaluated by micro-Kjeldahl method as described by Jackson [22]. Furthermore, Azotobacter isolates were screened for acetylene reduction ability (ARA) according to the methodologies of Marag and Suman [23], and the ARA results were expressed in nanomoles of ethylene produced per mg protein per hour.

2.6. In Vitro Studies on the Effect of Azotobacter on the Growth and Yield of Maize Seedlings. To study the effect of Azotobacter on maize (variety FEM-2), the pot experiments with selected Azotobacter strains with multiple PGP and high ARA activities were conducted in triplicate in a complete randomized design (CRD) as per our previous research [17]. The seeds treated with Azotobacter inoculant were sown whereas uninoculated control was also maintained. Different plant growth parameters, i.e., shoot length, root length, root number, leaf number, and chlorophyll content, were recorded after 30 days of germination.

2.7. Sequencing and Phylogenetic Analysis of $16 \mathrm{~S}$ rDNA of Potent Azotobacter Strains. The PCR amplified 16S rDNA regions of efficient Azotobacter were sequenced using an automated DNA Sequencer (ABI model 377, Applied Biosystems) as per the method described by Jain et al. [18]. The $16 \mathrm{~S}$ rDNA sequences were edited before the BLAST using the BioEdit software package. The sequences obtained in the study were compared with previously submitted sequences of the nucleotide database GenBank at National Centre for Biotechnology (NCBI) using the nucleotide BLAST (blastn) 
TABLE 1: PGPR activities of Azotobacter isolates.

\begin{tabular}{|c|c|c|c|c|c|}
\hline Isolates & IAA $(\mu \mathrm{g} / \mathrm{ml})$ & PSI $(\mathrm{cm})$ & SPI $(\mathrm{cm})$ & HCN production & $\mathrm{NH}_{3}$ production \\
\hline Azo1 & $26.5 \pm 1.31$ & $1.14 \pm 0.06$ & $1.5 \pm 0.08$ & ++ & ++ \\
\hline Azo2 & $25 \pm 1.21$ & NS & $1.5 \pm 0.09$ & ++ & ++ \\
\hline Azo3 & $24.5 \pm 1.22$ & NS & $1.45 \pm 0.07$ & +++ & +++ \\
\hline Azo4 & $34 \pm 1.8$ & $1.6 \pm 0.09$ & $1.2 \pm 0.06$ & +++ & +++ \\
\hline Azo5 & $25 \pm 1.25$ & NS & $1.4 \pm 0.07$ & + & ++ \\
\hline Azo6 & $26 \pm 1.34$ & NS & $1.08 \pm 0.05$ & +++ & ++ \\
\hline Azo7 & $33.5 \pm 1.68$ & $1.43 \pm 0.07$ & $1.17 \pm 0.06$ & +++ & +++ \\
\hline Azo8 & $25 \pm 1.26$ & NS & $1.25 \pm 0.07$ & +++ & +++ \\
\hline Azo9 & $17 \pm 0.91$ & NS & $1.42 \pm 0.09$ & +++ & ++ \\
\hline Azo10 & $31 \pm 1.56$ & NS & $1.46 \pm 0.09$ & +++ & +++ \\
\hline Azo11 & $24.5 \pm 1.26$ & NS & $1.46 \pm 0.05$ & +++ & +++ \\
\hline Azo12 & $20 \pm 1.11$ & NS & $1.58 \pm 0.08$ & ++ & ++ \\
\hline Azo13 & $20.5 \pm 1.04$ & NS & $1.5 \pm 0.08$ & +++ & ++ \\
\hline Azo14 & $26 \pm 1.33$ & $1.78 \pm 0.10$ & $1.67 \pm 0.08$ & + & ++ \\
\hline Azo15 & $28.5 \pm 1.42$ & $3.61 \pm 0.18$ & $1.29 \pm 0.06$ & +++ & +++ \\
\hline Azol6 & $16.5 \pm 0.87$ & NS & $1.66 \pm 0.09$ & ++ & ++ \\
\hline Azo17 & $31.5 \pm 1.59$ & NS & $1.45 \pm 0.06$ & +++ & +++ \\
\hline Azo18 & $27 \pm 1.37$ & NS & $1.29 \pm 0.06$ & +++ & ++ \\
\hline Azo19 & $26.5 \pm 1.33$ & NS & $1.35 \pm 0.07$ & +++ & ++ \\
\hline Azo20 & $22.5 \pm 1.13$ & $1.67 \pm 0.08$ & $1.64 \pm 0.08$ & ++ & + \\
\hline Azo21 & $20 \pm 1.12$ & NS & $1.81 \pm 0.09$ & +++ & +++ \\
\hline Azo22 & $22 \pm 1.11$ & NS & $1.29 \pm 0.06$ & +++ & ++ \\
\hline Azo23 & $24 \pm 1.24$ & NS & $1.53 \pm 0.07$ & + & +++ \\
\hline Azo24 & $21 \pm 1.05$ & $1.26 \pm 0.07$ & $1.44 \pm 0.08$ & +++ & + \\
\hline
\end{tabular}

Value \pm SD. NS: no solubilization; PSI: phosphorus solubilizing index; SPI: siderophore production index.

[24]. The 16S rDNA consensus sequences were aligned using an online tool CLUSTAL-W [25]. This alignment was further used for phylogenetic tree construction through the MEGA 6.06 software using the Maximum Likelihood method [26].

\section{Results and Discussion}

3.1. Isolation and Characterization of the Azotobacter Strains. In the present study, 24 Azotobacter strains were isolated from different rhizospheric soil samples of Southern Rajasthan on Jensen's medium. The morphological characteristics of Azotobacter strains are summarized in Table S2 (Supplementary data sheet). Based on cell morphology and pigment production, these isolates were preliminary characterized as Azotobacter. All these isolates were able to grow in nitrogenfree medium without producing water-soluble pigments. Microscopic studies confirmed that all these strains are cyst forming gram-negative rods when examined under the microscope. The present findings were corroborated with those of Khosravi and Dolatabad [27] who isolated Azotobacter from rhizospheric soils from arid and semiarid regions of Iran.
3.2. Screening of Plant Growth Promoting (PGP) Attributes and Abiotic Stress Tolerance of Azotobacter Strains. All 24 Azotobacter strains were subjected to various plant growth promoting activities, and the results are summarized in Table 1. All 24 Azotobacter strains were able to produce IAA ranging from 16.5 to $34 \mu \mathrm{g} \mathrm{ml}^{-1}$ in media supplemented with tryptophan. The maximum IAA production was observed by Azo4 $\left(34 \mu \mathrm{g} \mathrm{ml}^{-1}\right)$ followed by Azo7 $\left(33.5 \mu \mathrm{g} \mathrm{ml}^{-1}\right)$ whereas the least by Azo16 $\left(16.5 \mu \mathrm{g} \mathrm{ml}^{-1}\right)$. In the present study, IAA production by Azotobacter strains were slightly higher as compared with an earlier report from Pandey et al. [11] where $23 \mu \mathrm{g} / \mathrm{ml}$ of IAA production was recorded in Azotobacter strain AU1.

Out of the 24 strains, only seven were phosphate solubilizers, and the phosphate solubilization index (PSI) ranged between 1.14 and 3.61, and the strain Azo15 showed the highest solubilization index, i.e., 3.61. Nosrati et al. [28] studied the phosphate solubilization potentials of twenty Azotobacter isolates and reported the PSI for these strains between $3.5 \pm 0.1$ and $1.4 \pm 0.1$ which was also observed in the present investigation.

In the present study, all 24 strains were found to be positive for siderophore production, which was determined by their ability to produce the distinct orange halo on the 

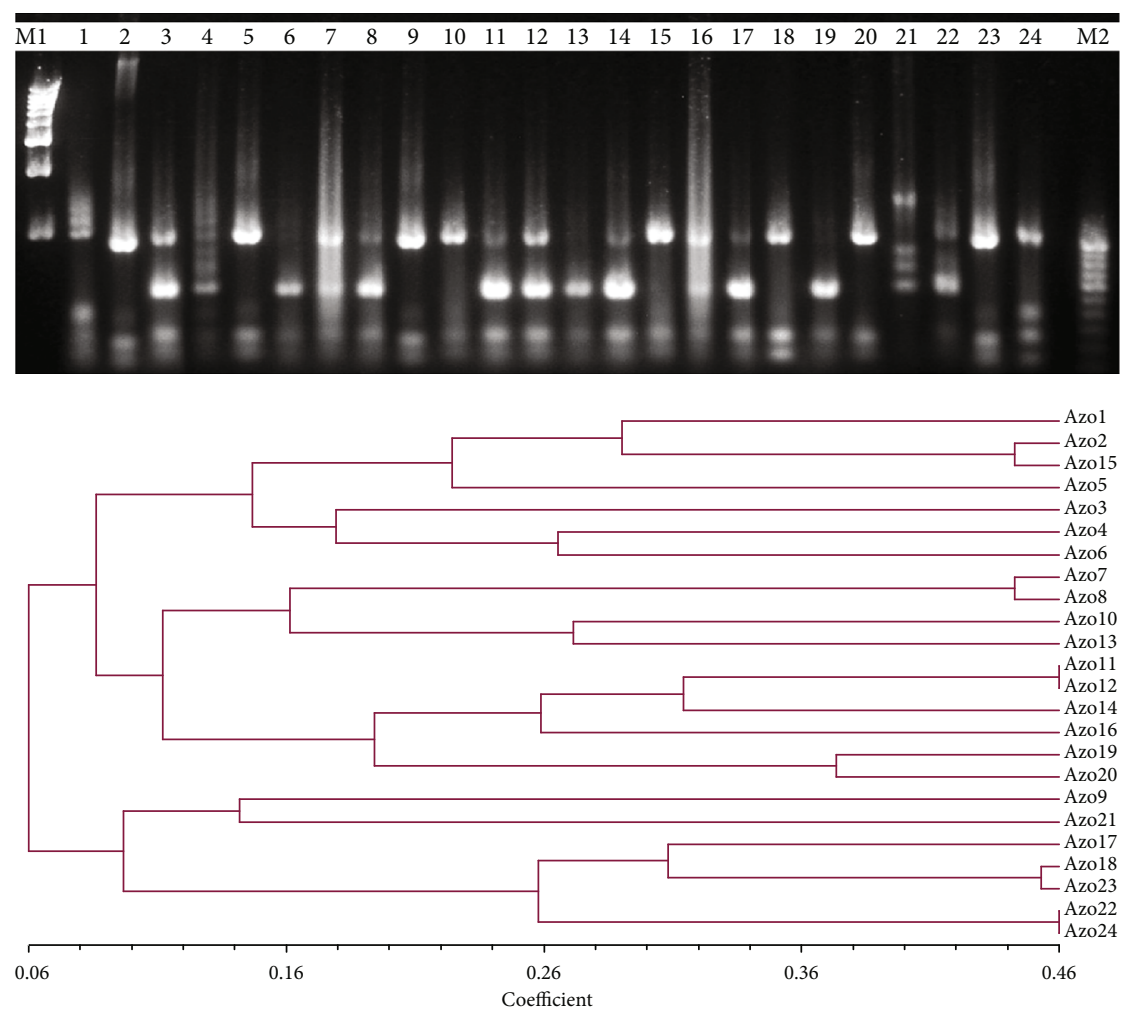

Figure 1: (a) Gel showing ARDRA pattern of 24 Azotobacter strains by Hinfl. (b) Dendrogram generated using UPGMA cluster analysis.

chrome azurol S (CAS) agar media. The highest siderophore production index was shown by Azo21 (1.81) whereas the least by Azo6 (1.08). Ferreira et al. [29] reported that A. vinelandii produced the highest levels of siderophore (80$140 \mu \mathrm{moll}^{-1}$ ) after $72 \mathrm{~h}$ incubation.

All Azotobacter strains were able to produce $\mathrm{HCN}$, and out of 24 isolates, 16 isolates exhibited strong $(+++)$ production, 5 isolates as moderate $(++)$, and 3 isolates as weak $(+)$. Whereas all Azotobacter strains were ammonia producers and 10 were recorded as strong $(+++)$ ammonia producers, 12 as moderate $(++)$ ammonia producers, and 2 showed poor (+) ammonia production. Chennappa et al. [30] studied the PGP activities of ten Azotobacter strains and reported that all strains were able to produce HCN and ammonia, which also supports finding of the present investigation.

The ability of Azotobacter strains to tolerate abiotic stress was also evaluated, and the results are summarized in supplementary data sheet (Table S3-S6). Among the 24 strains of Azotobacter, 6 strains exhibited growth at $\mathrm{pH} 4.0$; all the strains were able to grow at $\mathrm{pH} 6.0$, whereas 4 strains were able to grow at $\mathrm{pH} 8.0$ and one strain at $\mathrm{pH} 10.0$. Similar results were reported by Jimenez et al. [31] where pH6.07.0 were determined as optimum for Azotobacter strains isolated from different crop plant soil samples.

Azotobacter growth was also determined for salt tolerance using varying concentration of $\mathrm{NaCl}$ in Jensen broth. At 1-4\% $\mathrm{NaCl}$ concentration, all 24 strains showed profuse growth, and at $5 \% \mathrm{NaCl}$ concentration, 20 strains showed profuse growth, and 4 strains showed moderate growth, whereas at $6 \% \mathrm{NaCl}$ concentration, 7 strains showed profuse growth, and the remaining 17 strains showed moderate growth. At $7 \% \mathrm{NaCl}$ concentration, 3 strains showed moderate, and 13 strains showed week growth, and at $8 \% \mathrm{NaCl}$ concentration, 3 strains showed moderate, and 1 strain showed weak growth. At $9 \% \mathrm{NaCl}$ concentration, 2 strains showed moderate, and 2 showed weak growth, whereas at $10 \%$ salt concentration, only two strains showed weak growth. The above result agreed with the findings of Chennappa et al. [30] who studied four Azotobacter species for salt tolerance and reported that $A$. chroococcum, $A$. vinelandii, and $A$. salinestris can tolerate up to $8 \% \mathrm{NaCl}$ concentration; however, the cell counts were reduced with high concentration of $\mathrm{NaCl}$.

All 24 strains were subjected to temperature stress, and at $20^{\circ} \mathrm{C}$, poor growth was noted in 8 Azotobacter strains whereas moderate growth was observed in 16 isolates. At $30^{\circ} \mathrm{C}$, all 24 Azotobacter strains showed strong growth whereas at $35^{\circ} \mathrm{C}$ and $40^{\circ} \mathrm{C}$ only 2 strains and 1 strain, respectively, showed strong growth. At $45^{\circ} \mathrm{C}, 20$ Azotobacter strains showed poor growth, and 4 isolates failed to grow at this temperature. Similar results are corroborated by Chennapa et al. [30] where they studied temperature tolerance in Azotobacter and reported that the strains of $A$. chroococcum were found to be tolerant to the temperature range of $35-45^{\circ} \mathrm{C}$.

Azotobacter growth was determined for drought stress using varying concentration of PEG in Jensen broth. At 10\%, 20\%, 30\%, and 40\% PEG concentration, Azo18, Azo11, Azo10, and Azo7 strains showed moderate to high growth, respectively. Reports are available on PGP bacteria tolerance to drought stress $(20-40 \%)$ induced by PEG by Marulanda et al. [32]. Ali et al. [33] reported drought tolerance among thirty-two selected PGP bacterial isolates by PEG (6000) and hence could withstand under water stress conditions. 
TABLE 2: Qualitative and quantitative estimation of nitrogen fixation by Azotobacter strains.

\begin{tabular}{|c|c|c|c|}
\hline Isolates & $\begin{array}{l}\mathrm{N}_{2} \text { fixation using } \\
\text { NFMM with BTB* }\end{array}$ & $\begin{array}{l}\mathrm{N}_{2} \text { fixed }^{* *} \\
\text { (mg g }^{-1} \\
\text { sucrose })\end{array}$ & $\begin{array}{c}\text { ARA }^{* * *}(\mathrm{nmol} \\
\mathrm{C}_{2} \mathrm{H}_{4} \mathrm{mg} \\
\left.\text { protein }^{-1} \mathrm{hr}^{-1}\right)\end{array}$ \\
\hline Azo1 & Positive & $24.197 \pm 0.97$ & $846.561 \pm 40.02$ \\
\hline Azo2 & Positive & $6.672 \pm 0.3$ & $6.138 \pm 0.29$ \\
\hline Azo3 & Positive & $4.411 \pm 0.22$ & $46.804 \pm 2.39$ \\
\hline Azo4 & Positive & $7.519 \pm 0.36$ & $70.582 \pm 3.8$ \\
\hline Azo5 & Positive & $20.239 \pm 0.95$ & $47.968 \pm 2.06$ \\
\hline Azo6 & Negative & $6.672 \pm 0.3$ & $2.106 \pm 0.25$ \\
\hline Azo7 & Positive & $15.435 \pm 0.71$ & $343.947 \pm 18.01$ \\
\hline Azo8 & Positive & $6.672 \pm 0.2$ & $85.926 \pm 4.01$ \\
\hline Azo9 & Positive & $8.085 \pm 0.39$ & $55.344 \pm 2.46$ \\
\hline Azo10 & Positive & $4.411 \pm 0.2$ & $45.397 \pm 2.20$ \\
\hline Azo11 & Positive & $9.216 \pm 0.41$ & $139.788 \pm 7$ \\
\hline Azo12 & Negative & $8.368 \pm 0.44$ & $10.529 \pm 0.64$ \\
\hline Azo13 & Positive & $12.890 \pm 0.67$ & $261.143 \pm 11.08$ \\
\hline Azo14 & Positive & $17.413 \pm 0.69$ & $66.455 \pm 3.01$ \\
\hline Azo15 & Positive & $14.021 \pm 0.7$ & $283.122 \pm 14$ \\
\hline Azo16 & Negative & $6.954 \pm 0.29$ & $1.3122 \pm 0.06$ \\
\hline Azol7 & Positive & $6.389 \pm 0.3$ & $80.614 \pm 4.1$ \\
\hline Azo18 & Positive & $10.063 \pm 0.5$ & $159.048 \pm 6$ \\
\hline Azo19 & Positive & $6.106 \pm 0.32$ & $4.317 \pm 0.3$ \\
\hline Azo20 & Positive & $17.130 \pm 0.85$ & $668.519 \pm 33.01$ \\
\hline Azo21 & Positive & $5.824 \pm 0.3$ & $4.359 \pm 0.2$ \\
\hline Azo22 & Negative & $3.173 \pm 0.13$ & $8.265 \pm 0.5$ \\
\hline Azo23 & Positive & $5.824 \pm 0.3$ & $46.402 \pm 2.5$ \\
\hline Azo24 & Positive & $4.976 \pm 0.2$ & $45.513 \pm 1.9$ \\
\hline $\begin{array}{l}C D \text { at } \\
5 \%\end{array}$ & - & 0.748152188 & 17.03123459 \\
\hline CV\% & - & 4.695825426 & 7.468182458 \\
\hline
\end{tabular}

Value \pm standard deviation. ${ }^{*}$ Positive Azotobacter strains produced a blue color zone on the medium indicating the nitrogen fixation; ${ }^{* *}$ using microKjeldhal method; ${ }^{* * *}$ acetylene reduction assay.

3.3. Molecular Characterization Using ARDRA. The genetic diversity among the twenty-four Azotobacter isolates was assessed by the PCR-RFLP of $16 \mathrm{~S}$ rDNA. Three restriction endonucleases viz. Hinfl, AluI, and TaqI produced 57 banding patterns of varying sizes in 24 Azotobacter strains upon digestion of the 16S rDNA amplicon (Figure 1(a)). On the basis of restriction digestion by Hinfl, 21 different patterns were obtained, whereas digestion by TaqI and AluI produced 16 and 20 different patterns, respectively. Based on UPGMA clustering analysis, the Azotobacter strains showed significant molecular diversity, and the dendrogram obtained differentiated 24 strains into 2 major clusters A and B comprising 17 and 7 strains, respectively, at the similarly coefficient of 0.10 (Figure 1(b)). Similarity indices established on the basis 57 bands of the three restriction enzymes ranged from 0.04 to
0.45. Genetic relationship among 24 Azotobacter strains was also visualized by performing PCA, and the Azotobacter strains occupied the same position in two-dimensional and three-dimensional scaling as observed in the dendrogram. Therefore, different fingerprinting profiles were obtained which showed significant genetic diversity of Azotobacter strains selected from different districts of southern Rajasthan.

Rubio et al. [34] identified genetic diversity among $A$. chroococcum, A. salinestris, and A. Armeniacus by PCRRFLP of 16S rDNA sequences using the enzymes RsaI and HhaI. Mazinani and Asgharzadeh [35] also reported the molecular identification of three Azotobacter sp., i.e., A. chroococcum, A. vinelandii, and A. beijernckii using RsaI, HpaII, and HhaI. Khosravi and Dolatabad [27] studied the molecular differentiation and diversity analysis of Azotobacter species and reported that the ARDRA technique with HpaII, BOX, and REP PCR based markers was able to differentiate between A. chroococcum and A. salinestris.

3.4. Detection of Nitrogen Fixing Activity. To identify the free nitrogen fixers among these isolates, they were preliminary screened on nitrogen-free malate agar medium (NFMM) containing bromothymol blue (BTB) as an indicator. Out of 24 isolates, twenty Azotobacter strains produced a blue color zone on the medium indicating the fixation of nitrogen by them. The studies by Suleiman et al. [36] and Gothwal et al. [37] also reported a similar result. Furthermore, the amounts of total $\mathrm{N}_{2}$ fixed by Azotobacter strains ranged between 3.17 and $24.19 \mathrm{mg} \mathrm{g}^{-1}$ sucrose using micro-Kjeldhal method (Table 2). The highest amount of $\mathrm{N}_{2}$ was fixed by Azo1 while the lowest by Azo22. Upadhyay et al. [13] reported the amounts of $\mathrm{N}_{2}$ fixed by different Azotobacter strains ranged from 18.88 to $6.04 \mathrm{mgg}^{-1}$ sucrose and is in close agreement with the results of $\mathrm{N}_{2}$ fixation in the present study.

Acetylene reduction assay (nitrogenase activity) was used as an estimation of the rate of nitrogen fixation by Azotobacter [38]. The Azotobacter strains showed the ARA activity in the range from $1.312 \pm 0.06$ to $846.561 \pm 40.02 \mathrm{nmol} \mathrm{C}_{2} \mathrm{H}_{4}$ produced $\mathrm{mg}$ protein ${ }^{-1} \mathrm{~h}^{-1}$. Maximum nitrogenase of $846.561 \pm 40.02 \mathrm{nmol} \mathrm{C}_{2} \mathrm{H}_{4}$ produced $\mathrm{mg}_{\text {protein }}^{-1} \mathrm{~h}^{-1}$ was observed for isolate Azol, and the least ARA activity of $1.312 \pm 0.06 \mathrm{nmol} \mathrm{C}_{2} \mathrm{H}_{4} \mathrm{mg}$ protein ${ }^{-1} \mathrm{~h}^{-1}$ was observed for Azo16. Nosrati et al. [28] recorded amounts of acetylene reduced by $A$. vinelandii isolates in the range of 12.1 to $326.4 \mathrm{nmol} \mathrm{C}_{2} \mathrm{H}_{4} \mathrm{~h}^{-1}$ vial $^{-1}$.

3.5. In Vitro Studies on the Effect of Azotobacter on the Growth and Yield of Maize Seedlings. The pot culture experiment was conducted in plastic pots filled with sterile planting mixture. To study the plant growth promoting activity of Azotobacter isolates, maize cultivable variety (FEM-2) seeds were treated with Azotobacter inoculant (seed bacterization method) and sown. Fourteen Azotobacter strains were selected for pot studies based on their higher ARA values. Pot experiment data recorded after 30 days of germination are summarized in Table 3.

Higher plant growth was observed in maize seedlings raised from bacterized seeds with selected Azotobacter isolates compared with absolute control. This indicates the 
TABLE 3: In vitro studies on the effect of Azotobacter on growth and yield of maize seedling.

\begin{tabular}{|c|c|c|c|c|c|c|}
\hline $\begin{array}{l}\text { S. } \\
\text { no. }\end{array}$ & Treatment & $\begin{array}{l}\text { Average shoot length } \\
(\mathrm{cm})\end{array}$ & $\begin{array}{l}\text { Average root length } \\
(\mathrm{cm})\end{array}$ & $\begin{array}{c}\text { Average root } \\
\text { number }\end{array}$ & $\begin{array}{c}\text { Average leaf } \\
\text { number }\end{array}$ & $\begin{array}{c}\text { Total chlorophyll } \\
(\mu \mathrm{g} / \mathrm{ml})\end{array}$ \\
\hline$\overline{1}$ & Control & $12.5 \pm 0.12^{\mathrm{cd}}$ & $31.5 \pm 0.66^{\mathrm{ef}}$ & $9.66 \pm 0.58^{f}$ & $5 \pm 1.0^{\mathrm{a}}$ & $30.14 \pm 0.95^{\mathrm{i}}$ \\
\hline 2 & Azo1 & $18.9 \pm 0.20^{\mathrm{a}}$ & $38.5 \pm 0.95^{\mathrm{c}}$ & $18.33 \pm 1.15^{\mathrm{a}}$ & $6.3 \pm 0.58^{\mathrm{a}}$ & $52.83 \pm 1.90^{\mathrm{ab}}$ \\
\hline 3 & Azo3 & $12 \pm 0.50^{\mathrm{d}}$ & $31.65 \pm 0.96^{\mathrm{ef}}$ & $10.67 \pm 0.58^{\mathrm{ef}}$ & $5.3 \pm 1.53^{\mathrm{a}}$ & $31.56 \pm 1.49^{\mathrm{hi}}$ \\
\hline 4 & Azo5 & $12 \pm 0.38^{\mathrm{d}}$ & $32.45 \pm 1.05^{\mathrm{ef}}$ & $11.67 \pm 0.58^{\mathrm{def}}$ & $5 \pm 0.0^{\mathrm{a}}$ & $34.71 \pm 1.20^{\text {fghi }}$ \\
\hline 5 & Azo7 & $17.95 \pm 0.51^{\mathrm{a}}$ & $38.69 \pm 1.03^{c}$ & $17.67 \pm 0.58^{\mathrm{ab}}$ & $5.67 \pm 0.58^{\mathrm{a}}$ & $48.50 \pm 1.15^{\mathrm{bc}}$ \\
\hline 6 & Azo9 & $13.56 \pm 0.52^{\mathrm{bcd}}$ & $31.12 \pm 0.98^{f}$ & $10.33 \pm 1.53^{\mathrm{ef}}$ & $6.3 \pm 0.58^{\mathrm{a}}$ & $35.72 \pm 1.27^{\mathrm{fgh}}$ \\
\hline 7 & Azo11 & $14.23 \pm 1.16^{\mathrm{bc}}$ & $32.78 \pm 1.07^{\mathrm{ef}}$ & $10.67 \pm 1.15^{\mathrm{ef}}$ & $5.3 \pm 0.58^{\mathrm{a}}$ & $32.49 \pm 1.98^{\mathrm{ghi}}$ \\
\hline 8 & Azo13 & $18.2 \pm 0.62^{\mathrm{a}}$ & $47.23 \pm 0.94^{\mathrm{ab}}$ & $18.33 \pm 1.53^{\mathrm{a}}$ & $6.3 \pm 0.58^{\mathrm{a}}$ & $47.1 \pm 1.86^{\mathrm{cd}}$ \\
\hline 9 & Azo14 & $11.88 \pm 0.58^{\mathrm{d}}$ & $32.3 \pm 1.12^{\mathrm{ef}}$ & $10.67 \pm 1.53^{\mathrm{ef}}$ & $5 \pm 0.0^{\mathrm{a}}$ & $39.2 \pm 2.05^{\mathrm{ef}}$ \\
\hline 10 & Azo15 & $17.68 \pm 0.51^{\mathrm{a}}$ & $45.95 \pm 1.90^{\mathrm{b}}$ & $16.33 \pm 1.15^{\mathrm{abc}}$ & $5.3 \pm 0.58^{\mathrm{a}}$ & $42.85 \pm 2.26^{\mathrm{de}}$ \\
\hline 11 & Azol7 & $14.59 \pm 1.02^{\mathrm{b}}$ & $32.96 \pm 1.10^{\mathrm{ef}}$ & $13.67 \pm 0.58^{\mathrm{cde}}$ & $5.67 \pm 0.58^{\mathrm{a}}$ & $37.87 \pm 2.15^{\mathrm{efg}}$ \\
\hline 12 & Azo18 & $13.26 \pm 0.54^{\mathrm{bcd}}$ & $38.16 \pm 0.93^{c}$ & $13.33 \pm 0.58^{\mathrm{cde}}$ & $6.3 \pm 0.58^{\mathrm{a}}$ & $37.13 \pm 2.05^{\mathrm{fg}}$ \\
\hline 13 & Azo20 & $18.49 \pm 0.62^{\mathrm{a}}$ & $49.58 \pm 1.15^{\mathrm{a}}$ & $16.67 \pm 2.08^{\mathrm{abc}}$ & $6.67 \pm 0.58^{\mathrm{a}}$ & $54.39 \pm 2.90^{\mathrm{a}}$ \\
\hline 14 & Azo23 & $13.85 \pm 1.05^{\mathrm{bcd}}$ & $37.23 \pm 1.2^{\mathrm{cd}}$ & $14.33 \pm 0.58^{\mathrm{bcd}}$ & $5.3 \pm 0.58^{\mathrm{a}}$ & $38.67 \pm 1.08^{\mathrm{ef}}$ \\
\hline \multirow[t]{3}{*}{15} & Azo24 & $14.34 \pm 1.04^{\mathrm{bc}}$ & $34.54 \pm 1.24^{\mathrm{de}}$ & $11.66 \pm 1.53^{\mathrm{def}}$ & $5 \pm 0.0^{\mathrm{a}}$ & $34.76 \pm 2.05^{\mathrm{fghi}}$ \\
\hline & $\mathrm{CD}$ at $5 \%$ & 1.110036913 & 1.91982297 & 1.731219988 & 1.128863211 & 3.009485161 \\
\hline & $\mathrm{CV} \%$ & 4.454842219 & 3.103901796 & 7.611017199 & 11.95775004 & 4.513783099 \\
\hline
\end{tabular}

Each value is a mean of 3 replicates from 2 experiments. Mean \pm SD followed by the same letter in a column of each treatment is not a significant difference at $p=0.05$ by the Tukey-Kramer HSD test. Data are recorded after 30 days of germination.

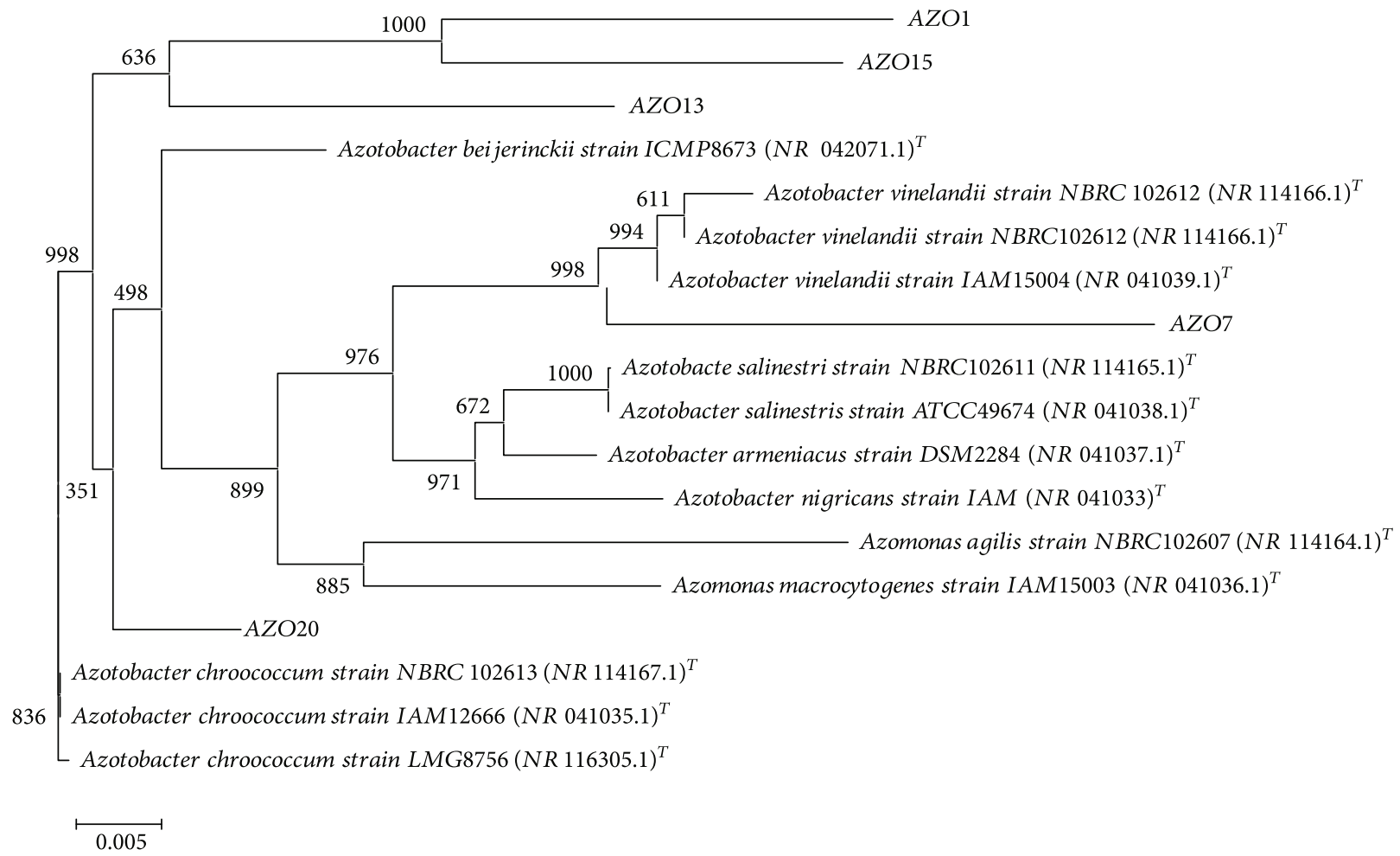

FIgure 2: Phylogenetic tree of native Azotobacter strains based on the 16S rDNA with closely related type strains using the MEGA 6.06 software. GenBank accession numbers (in parenthesis) are listed after the species names. Bootstrap values are indicated at branching points. The scale bar indicates five base substitutions for 100 nucleotide positions. 
TABLE 4: Identification of native Azotobacter strains by $16 \mathrm{~S}$ rDNA sequencing.

\begin{tabular}{lcccc}
\hline Strain & Molecular identity & GenBank accession no. & Species (strain) & Accession no. \\
\hline Azo1 & Azotobacter chroococcum & MT312860 & Azotobacterchroococcum strain LMG 8756 & NR_116305 \\
Azo7 & Azotobacter vinelandii & MT312861 & Azotobactervinelandii strain NBRC 102612 & NR_114166 \\
Azo13 & Azotobacter chroococcum & MT312862 & Azotobacterchroococcum strain NBRC 102613 & NR_114167 \\
Azo15 & Azotobacter chroococcum & MT312863 & Azotobacterchroococcum strain IAM 12666 & NR_041035 \\
Azo20 & Azotobacter chroococcum & MT312864 & Azotobacterchroococcum strain NBRC 102613 & NR_114167 \\
\hline
\end{tabular}

positive effect of Azotobacter strains on maize plantlets. Shoot length, root length, root number, and total chlorophyll content have been significantly increased in the maize plantlets inoculated with the selected Azotobacter strains as compared to uninoculated control.

Shoot length increases by $51.20 \%$ in pots inoculated with Azo1 followed by Azo20 (47.92\%). Root length increases by $57.39 \%$ in pots inoculated with Azo20 followed by Azo13 (49.94\%). Root number increases by $89.75 \%$ in pots inoculated with Azo1 and Azo13. Leaf number increases by $33.4 \%$ in pot inoculated with Azo20 followed by Azo1 and Azo13 (26.0\%). Chlorophyll content increased by $80.46 \%$ in pots inoculated with Azo20 followed by Azo1 (75.28\%). All Azotobacter strains significantly influenced the observed parameters as compared to uninoculated control and contributed to plant growth. Similar finding was observed by Mahato and Neupane [39] who reported Azotobacter seed bacterization in maize stimulated the growth of treated plants as characterized by the increase of root and shoot length. Romero-Perdomo et al. [40] reported Azotobacter bacterial inoculation in cotton positively influenced plant growth parameters reducing $50 \%$ nitrogen fertilization dose. These findings advocated the application of Azotobacter for the improvement of plant growth due to their intrinsic ability of fixing atmospheric nitrogen and expressing plant growth-promoting substances.

3.6. Molecular Identification of the Isolates. The full length sequence of $16 \mathrm{~S}$ rDNA gene of the most promising Azotobacter strains based on the multiple PGP activities, nitrogen fixation ability, and in vitro performance viz. Azo1, Azo7, Azo13, Azo15, and Azo20 were sequenced and analyzed using the nucleotide BLAST tool. Based on the BLAST results, these strains showed the greatest sequence identity with the previously reported type strains of Azotobacter chroococcum and Azotobacter vinelandii (Figure 2). Indian soils are previously reported to have both chroococcum and vinelandii species of Azotobacter [11,41] also supporting the present study. The molecular identities and NCBI GenBank accession number assigned to these strains are presented in Table 4.

In the present study, biochemical and molecular characterization of Azotobacter strains was reported from the soils of Southern Rajasthan, and based on 16S rDNA sequencing, the potent strain was characterized as Azotobacter chroococcum and Azotobacter vinelandii. In this research, additional molecular techniques including ARDRA revealed significant genetic diversity among Azotobacter strains studied in this study. The plant growth promoting traits and nitrogen fixation by local Azotobacter strains is very critical for the selection of such strains for biofertilizer formulations in order to replace the ineffective strains. The results indicated that inoculation with multi-PGP Azotobacter strains significantly improved the plant growth under in vitro conditions and may be used for commercial production. Hence, dedicated field studies are required to confirm the efficacy of these Azotobacter strains.

\section{Data Availability}

The data used to support the findings of this study are included within the supplementary information file(s).

\section{Conflicts of Interest}

No potential conflict of interest was reported by the authors.

\section{Authors' Contributions}

DJ, SRM, and EM conceived and designed the experiments. JS, GK, AAB, and SC performed the laboratory experiments. AS performed the ARA. EM, DJ, and VS wrote the manuscript. All authors read and approved the final manuscript. DJ and JS contributed equally to the work.

\section{Acknowledgments}

The financial assistance from the All India Network Project on soil biodiversity and biofertilizers and the Rastriya Krishi VikasYojana (RKVY) research project is highly acknowledged.

\section{Supplementary Materials}

Table S1: location of different isolated Azotobacter strains from Rajasthan. Table S2: morphological characterization of Azotobacter isolates. Table S3: pH tolerance in Azotobacter isolates. Table S4: temperature stress tolerance in Azotobacter isolates. Table S5: salinity tolerance in Azotobacter isolates. Table S6: drought tolerance in Azotobacter isolates (Supplementary Materials)

\section{References}

[1] X. E. Pantazi, D. Moshou, and D. Bochtis, Intelligent Data Mining and Fusion Systems in Agriculture. Utilization of multisensors and data fusion in precision agriculture, Academic Press, San Diego (CA), 2020. 
[2] L. Liu, C. Zhu, S. Xu, Y. Li, H. X. Zheng, and R. Shi, "Combined application of organic and inorganic nitrogen fertilizers affects soil prokaryotic communities compositions," Agronomy, vol. 10, no. 1, p. 132, 2020.

[3] S. Timmusk, L. Behers, J. Muthoni, A. Muraya, and A. C. Aronsson, "Perspectives and challenges of microbial application for crop improvement," Frontiers in Plant Science, vol. 8, p. 49, 2017.

[4] S. E. Fischer, S. I. Fischer, S. Magris, and G. B. Mori, "Isolation and characterization of bacteria from the rhizosphere of wheat," World Journal of Microbiology and Biotechnology, vol. 23, no. 7, pp. 895-903, 2007.

[5] E. R. Eid, M. N. Awad, and H. A. Hamouda, "Evaluate effectiveness of bio and mineral fertilization on the growth parameters and marketable cut flowers of Matthio laincana L.," American-Eurasian Journal of Agricultural and Environmental Science, vol. 5, pp. 509-518, 2009.

[6] J. González-López, "Microorganismos diazotrofos asociados a raíces de plantas no leguminosas," in Interacción PlantaMicroorganismo, J. González-López and C. Lluch, Eds., Biología del Nitrógeno, Rueda, Madrid, Spain, 1992.

[7] S. Martyniuk and M. Martyniuk, "Occurrence of Azotobacter spp. in some polish soils," Polish Journal of Environmental Studies, vol. 12, pp. 371-374, 2003.

[8] A. Namvar and T. Khandan, "Response of wheat to mineral nitrogen fertilizer and biofertilizer (Azotobacter sp. and Azospirillum sp.) inoculation under different levels of weed interference," Ekologija, vol. 59, pp. 85-94, 2013.

[9] A. Amiri and M. Rafiee, "Effect of soil inoculation with Azospirillum and Azotobacter bacteria on nitrogen use efficiency and agronomic characteristics of corn," Annals of Biological Research, vol. 4, pp. 77-79, 2013.

[10] J. Yang, J. W. Kloepper, and C. M. Ryu, "Rhizosphere bacteria help plants tolerate abiotic stress," Trends in Plant Science, vol. 14, no. 1, pp. 1-4, 2009.

[11] S. Pandey, S. Gupta, and N. Ramawat, "Unravelling the potential of microbes isolated from rhizospheric soil of chickpea (Cicer arietinum) as plant growth promoter," 3 Biotech, vol. 9, no. 7, p. 277, 2019.

[12] A. Khalid, M. Arshad, and Z. A. Zahir, "Screening plant growth-promoting rhizobacteria for improving growth and yield of wheat," Journal of Applied Microbiology, vol. 96, no. 3, pp. 473-480, 2004.

[13] S. Upadhyay, N. Kumar, V. K. Singh, and A. Singh, "Isolation, characterization and morphological study of Azotobacter isolates," Journal of Applied and Natural Science, vol. 7, no. 2, pp. 984-990, 2015.

[14] H. L. Jensen, "Non-symbiotic nitrogen fixation, in Soil Nitrogen Series of Agronomy," in Mongr. No. 10, W. V. Bartholomew and F. E. Clark, Eds., American Society of Agronomy Madison, Wisconsin, 1965.

[15] J. Bush and P. A. Wilson, "A Non-Gummy Chromogenic Strain of Azotobacter vinelandii," Nature, vol. 184, no. 4683, pp. 381-382, 1959.

[16] G. R. Vela and G. Cagle, "Formation of fragile cysts by a strain of Azotobacter chroococcum," Journal of General Microbiology, vol. 57, no. 3, pp. 365-368, 1969.

[17] R. Kour, D. Jain, A. A. Bhojiya et al., "Zinc biosorption, biochemical and molecular characterization of plant growthpromoting zinc-tolerant bacteria," 3 Biotech, vol. 9, p. 421, 2019.
[18] D. Jain, S. Sanadhya, H. Saheewala et al., "Molecular diversity analysis of plant growth promoting Rhizobium isolated from groundnut and evaluation of their field efficacy," Current Microbiology, vol. 77, no. 8, pp. 1550-1557, 2020.

[19] D. Jain, S. D. Sunda, S. Sanadhya, D. J. Nath, and S. K. Khandelwal, "Molecular characterization and PCR-based screening of cry genes from Bacillus thuringiensis strains," 3 Biotech, vol. 7, no. 1, 2017.

[20] C. A. Cihan, N. Tekin, B. Ozcan, and C. Cokmus, "The genetic diversity of genus Bacillus and the related genera revealed by 16s rRNA gene sequences and ARDRA analyses isolated from geothermal regions of Turkey," Brazilian Journal of Microbiology, vol. 43, no. 1, pp. 309-324, 2012.

[21] F. J. Rohlf, NTSYSpc numerical taxonomy and multivariate analysis system version 2.0 user guide, Applied Biostatistics Inc, Setauket, New York, 1998.

[22] M. L. Jackson, Soil Chemical Analysis, Prentice Hall of India Pvt. Ltd., New Delhi, 1967.

[23] P. S. Marag and A. Suman, "Growth stage and tissue specific colonization of endophytic bacteria having plant growth promoting traits in hybrid and composite maize (Zea mays L.)," Microbiological Research, vol. 214, pp. 101-113, 2018.

[24] S. F. Altschul, W. Gish, W. Miller, E. W. Myers, and D. J. Lipman, "Basic local alignment search tool," Journal of Molecular Biology, vol. 215, no. 3, pp. 403-410, 1990.

[25] J. D. Thompson, D. G. Higgins, and J. Gibson, "CLUSTAL W: improving the sensitivity of progressive multiple sequence alignment through sequence weighting, position-specific gap penalties and weight matrix choice," Nucleic Acids Research, vol. 22, no. 22, pp. 4673-4680, 1994.

[26] K. Tamura, G. Stecher, D. Peterson, A. Filipski, and S. Kumar, "MEGA6: molecular evolutionary genetics analysis version 6.0.," Molecular Biology and Evolution, vol. 30, no. 12, pp. 2725-2729, 2013.

[27] H. Khosravi and H. K. Dolatabad, "Identification and molecular characterization of Azotobacter chroococcum and Azotobacter salinestris using ARDRA, REP, ERIC, and BOX," Molecular Biology Reports, vol. 47, no. 1, pp. 307-316, 2020.

[28] R. Nosrati, P. Owlia, H. Saderi, I. Rasooli, and M. A. Malboobi, "Phosphate solubilization characteristics of efficient nitrogen fixing soil Azotobacter strains," Iranian journal of microbiology, vol. 6, no. 4, pp. 285-295, 2014.

[29] C. M. H. Ferreira, Â. Vilas-Boas, C. A. Sousa, H. M. V. M. Soares, and E. V. Soares, "Comparison of five bacterial strains producing siderophores with ability to chelate iron under alkaline conditions," AMB Express, vol. 9, no. 1, p. 78, 2019.

[30] G. Chennappa, M. K. Naik, C. R. Adkar-Purushothama, Y. S. Amaresh, and M. Y. Sreenivasa, "PGP potential, abiotic stress tolerance and antifungal activity of Azotobacter strains isolated from paddy soils," Indian Journal of Experimental Biology, vol. 54, no. 5, pp. 322-331, 2016.

[31] D. J. Jiménez, J. S. Montaña, and M. M. Martínez, "Characterization of free nitrogen fixing bacteria of the genus $\mathrm{Azo}$ tobacter in organic vegetable-grown Colombian soils," Brazilian Journal of Microbiology, vol. 42, no. 3, pp. 846858, 2011.

[32] A. Marulanda, J. M. Barea, and R. Azcón, "Stimulation of plant growth and drought tolerance by native microorganisms (AM Fungi and bacteria) from dry environments: mechanisms related to bacterial effectiveness," Journal of Plant Growth Regulation, vol. 28, no. 2, pp. 115-124, 2009. 
[33] S. Z. Ali, V. Sandhya, and L. V. Rao, "Isolation and characterization of drought-tolerant ACC deaminase and exopolysaccharide producing fluorescent Pseudomonas sp," Annals of microbiology, vol. 64, pp. 493-502, 2014.

[34] E. J. Rubio, M. S. Montecchia, M. Tosi, F. D. Cassan, A. Perticari, and O. S. Correa, "Genotypic characterization of azotobacteria isolated from Argentinean soils and plantgrowth-promoting traits of selected strains with prospects for biofertilizer production," The Scientific World Journal, vol. 2013, Article ID 519603, 12 pages, 2013.

[35] Z. Mazinani and A. Asgharzadeh, "Genetic diversity of Azotobacter strains isolated from soils by amplified ribosomal DNA restriction analysis," Cytology and Genetics, vol. 48, no. 5, pp. 293-301, 2014.

[36] M. K. Suleiman, A. M. Quoreshi, N. R. Bhat, A. J. Manuvel, and M. T. Sivadasan, "Divulging diazotrophic bacterial community structure in Kuwait desert ecosystems and their $\mathrm{N}_{2}$-fixation potential," PLoS One, vol. 14, no. 12, p. e0220679, 2019.

[37] R. K. Gothwal, V. K. Nigam, M. K. Mohan, D. Sasmal, and P. Ghosh, "Screening of nitrogen fixers from rhizospheric bacterial isolates associated with important desert plants," Applied Ecology and Environmental Research, vol. 6, no. 2, pp. 101109, 2008.

[38] V. M. Hitchins and H. L. Sadoff, "Sequential metabolic events during encystment of Azobacter vinelandii1," Journal of Bacteriology, vol. 113, no. 3, pp. 1273-1279, 1973.

[39] S. Mahato and S. Neupane, "Comparative study of impact of Azotobacter and Trichoderma with other fertilizers on maize growth," Journal of Maize Research and Development, vol. 3, no. 1, pp. 1-16, 2017.

[40] F. Romero-Perdomo, J. Abril, M. Camelo et al., “Azotobacter chroococcum como biofertilizante bacteriano potencialmente util para el algodon (Gossypium hirsutum L.): efecto en la reducci on de la fertilizacion nitrogenada," Revista Argentina de Microbiología, vol. 49, no. 4, pp. 377-383, 2017.

[41] R. K. Sahoo, M. W. Ansari, M. Pradhan, T. K. Dangar, S. Mohanty, and N. Tuteja, "A novel Azotobacter vinellandii (SRIAz3) functions in salinity stress tolerance in rice," Plant Signaling \& Behavior, vol. 9, no. 7, p. e29377, 2014. 